\section{Professor Serge C. Renaud (1927-2012): French Paradox and wine active compounds}

\author{
Dominique Lanzmann-Petithory \\ Groupe Hospitalier Henri Mondor, \\ Hôpital Émile Roux, Limeil-Brévannes, \\ France
}

\section{Dear Editor,}

Professor Serge Renaud is worldwide known as the father of the French Paradox: low French coronary heart disease (CHD) mortality despite higher risk factors such as saturated fatty acids (SFA) consumption. The Paradox may be partially due to moderate wine consumption. Over many decades, he was the scientist who initiated most of the work relating the consumption of wine to cardiovascular disease. Prof. Renaud is also known as the father of the Cretan diet, an alpha-linolenic acid (ALA) rich diet.

Half-French, half-Canadian, Prof. Renaud grew up in the Bordeaux region, the Blayais, where his two grandfathers had a vineyard. After beginning his medical training in France, he moved to Canada in 1951 with his dear cousin Raymond, who is still alive in Berkeley at 93 years of age. Both were lumberjacks in the Laurentides to pay for university costs. When I left France at the age of 24, I couldn't imagine there was a population in the world that didn't drink wine with meals, he said. He immediately noted the bad dietary habits in Québec: no fruits, few vegetables, lots of SFA, and no wine. He observed that there were frequent episodes of myocardial infarction (MI), even in young hockey players, among this population that had the same genes as French people.

After finishing his training and receiving the Veterinary VMD degree in 1957, where he was first in his class at Saint-Hyacinthe, Montreal, he chose to devote himself entirely to research. His first scientific paper was published in 1957 with Hans Selyé, ${ }^{1}$ the inventor of stress, with whom he made a brilliant start to his career. Hans Selyé wanted him to become his principal assistant. Prof. Renaud preferred instead to focus his research on diet as a key factor in the development of CHD. He was awarded a PhD degree in Experimental Medicine and Surgery in 1960. Thirty years ahead of his time, he began to realize that thrombosis was the main event in MI, based especially on his observations of autopsy material, and that such thrombosis was independent on cholesterol levels.

Prof. Renaud was Head of the Laboratory of Experimental Pathology, Montreal Heart Institute, for 13 years. In 1971, he became
Visiting Professor at Boston University, in the Department of Pathology. He then returned to Montreal becoming Professor of Pathology, and then Professor and Director, Department of Nutrition, Faculty of Medicine, at the University of Montreal in 1975 . He returned part-time to France in 1973 to take care of his parents, and entered the National Institute of Health and Medical Research (INSERM) as director of Research Unit 63 in Lyon, within the Cardiology Hospital. He regretted the move to France in some ways, as research conditions in France where not those offered by Canada. He completed his academic carrier as Research Director INSERM Unit 330 in Bordeaux, where he remained until retirement; later he received an emeritus position there and went to his office every day for the next 10 years.

As early as the 1960, Prof. Renaud decided to investigate extensively the relationship between nutrition and thrombosis. He said himself that most of the success he had in research on CHD resulted from that decision. He developed an original method of research on platelet reactivity (PR) in humans, and launched a mobile laboratory to be able to reach rural populations of different countries to compare PR with dietary habits under controlled conditions. The first study in farmers from France suggested that PR, but not lipemia, could explain the higher CHD mortality in Moselle compared to that of Var. Risk factors such as SFA and smoking, and protective factors like calcium, alcohol, and polyphenols, were much more important than lipemia in influencing PR. This story is related in more detail to the obituary of the Journal of the International Society for the Study of Fatty Acids and Lipids (ISSFAL) devoted to fatty acids for which Prof. Renaud was a founding father. ${ }^{2}$

The Seven Country Study revealed that subjects in Crete were doing, or eating, something right, as Crete had by far the lowest CHD mortality rates of the seven countries and regions studied, despite having higher serum cholesterol. Something protects the Cretans which does not reduce their cholesterol, proposed Prof. Renaud. He guessed that it was ALA and designed then the most important and successful nutrition intervention trial: the Lyon Diet heart Trial, and obtained a 73\% decrease of myocardial infarction and 70\% decrease of all causes mortality with a Cretan type of diet, rich in ALA. ${ }^{3}$

While Prof. Renaud was visiting professor at Boston University, at the beginning of the 70s, he heard of the results of the Framingham study in which alcohol, supposedly a harmful factor in coronary heart disease, seemed, on the contrary, to protect from it, this to the huge astonishment of the epidemiologists at the National Institute of Health. The information
Correspondence: Dominique LanzmannPetithory, Groupe Hospitalier Henri Mondor, Hôpital Émile Roux, 51 Avenue du Maréchal de Lattre de Tassigny, 94451 Limeil-Brévannes Cedex, France.

Tel./Fax: +33.149 .812111 .

E-mail:_dominique.lanzmann@orange.fr; dominique.lanzmann@erx.aphp.fr

Key words: Serge Renaud, French Paradox, Cretan diet.

Presented at the $3^{\text {rd }}$ International Conference on Wine Active Compounds (WAC) - March $26^{\text {th }}-28^{\text {th }}$ 2014, Beaune, France.

Received for publication: 30 June 2014.

Revision received: 1 September 2014.

Accepted for publication: 2 September 2014.

This work is licensed under a Creative Commons Attribution 3.0 License (by-nc 3.0).

(C) Copyright D. Lanzmann-Petithory, 2014

Licensee PAGEPress, Italy

Wine Studies 2014; 3:4477

doi:10.4081/ws.2014.4477

was wilfully kept secret for several years, but Prof. Renaud considered it extremely important as it could partially explain, following his research on PR, French people's cardio-vascular protection.

On 17 November 1991, Morley Safer from 60 Minutes, the popular CBS television program in the United States, went to Prof. Renaud's laboratory INSERM 63 unit in Lyon with Dr. Curtis Ellison - Professor of Medicine and Public Health at Boston University School of Medicine - to ask his opinion on the cardiovascular protection of the French. ${ }^{4}$ Prof. Renaud suggested, taking great precautions, that alcohol could be one of the key protective factors. Morley Safer, holding a glass of red wine, concluded the television segment saying: The explanation of the French Paradox may lie in this inviting glass. At the request of thousands of Americans, it was re-broadcast several times and watched by more than fifty million Americans. Wine sales in the US increased by $40 \%$ in the following year, and exportation of French wines more than doubled between 1994 and 1998. The surveys carried out by Jon Fredrickson Gomberg and Fred in Sacramento showed that the increase in wine sales in the $90 \mathrm{~s}$ could be attributed to the 60 Minutes program on the French Paradox. During the same program, Prof. Renaud stated: First of all, in France, people pay more attention to the food, whether it is fresh, they even go to the market to purchase the fresh food and consequently the meal itself is something that takes time to prepare, takes time to eat, and the attitude toward the meal is somewhat different, and I am convinced that it is something 
that should be taken in consideration... If you drink alcohol in moderation, you will never get any adverse effect. People attempt to go beyond this moderate intake ... Alcohol is a drug and as any other drug, it has to be given at a proper dosage. Morley Safer: How old were you when you started to have a glass of wine at lunch? Prof. Renaud: Very young, at the age of 10 or 12 , but it was a little bit of wine and a large amount of water, during meals. A direct consequence of this highly successful program was that the US government (Federal Bureau of Alcohol, Tobacco and Firearms) asked Prof. Renaud to further develop his ideas in a request made through the French Ministry of Finance. Prof. Renaud thus published his seminal paper in Lancet defining the French Paradox: for a level of risk factors similar to that of countries such as the UK and the US (cholesterol, high blood pressure, smoking, saturated fat consumption), France has a lower CHD mortality rate than the majority of the rest of the industrialized world. ${ }^{5}$ Following the publication of this article, Prof. Renaud never received any other request from the American government. Two years later, the US Surgeon General suggested that a moderate intake of alcohol could be beneficial to health. It was the starting point of research on wine active compounds.

Prof. Renaud then developed his hypothesis that the habit of drinking moderate amounts of wine with meals could be beneficial to health, continuing to study this concept both in animals, in particular on the positive role of alcohol on blood platelets and especially wine in the prevention of the platelet rebound effect, ${ }^{6}$ and in humans.7 His hypothesis is backed up by numerous observational studies of the last twenty years. It is now quite well admitted that moderate regular intake of alcohol, particularly wine, appears to be associated with healthiest outcomes, ${ }^{8,9}$, whereas binge drinking is associated with higher cardio-vascular risk, ${ }^{10,11}$ twofold higher mortality among patients who survive acute myocardial infarction even among light drinkers, ${ }^{12}$ and higher risk of obesity: for example, in 8236 men and women, obesity of binge $v s$ no binge drinking had a relative risk of 1.77 (confidence interval=1.18-2.65). ${ }^{13}$ Prof. Renaud contributed to the consciousness of a French food model related to cardio-vascular protection. The French paradox is still observable today through the 2008 World Health Organization data. ${ }^{14}$ It is still true today that the French population has the second lowest cardio-vascular mortality after Japan despite higher smoking habits than in the UK and the US, and higher cholesterol levels. A recent comparison of French eating habits to Americans by CREDOC (Research Center for the study and observation of living conditions) showed that the French eat more saturated fat than Americans (33.4 vs $25.9 \mathrm{~g} /$ day). ${ }^{15}$ It means that the French Paradox concept of Prof. Renaud is a robust one. This CREDOC comparison also shows that in France wine accompanies the meal, while in the US alcoholic beverages are not necessarily associated with mealtime and may be consumed between meals.

Over fifteen years ago, Prof. Renaud launched a vast epidemiological population follow-up study with the Center for Preventive Medicine in Nancy. Thanks to this institution and to the head of statistical programs, René Guéguen, he was able to gather data on 100,000 subjects over a $20-25$ year period. It was the first study in France to have demonstrated that a moderate consumption of alcohol, particularly wine, was associated with a $40 \%$ reduction in cardio-vascular mortality in middle-aged men. ${ }^{16,17}$ This study was prolonged by his co-worker Dominique LanzmannPetithory under the form of a program financed by a public grant on wine and cancer. Scientists and medical doctors will find useful to read the tribute published by Bruno Simini in Lancet on 1 January 2000: Prof. Renaud, from French Paradox to Cretan miracle. ${ }^{18}$ Prof. Renaud also published books for the public, such as The healthy diet, in 1995, and The cretan diet, incredible protector of our health, in 2004. For his overall contribution to scientific research, Prof. Renaud received numerous prizes such as the award of the Fondation Française de Nutrition in 1983, and the Nestlé award of Nutrition in 1997. In 2005, he received the highest distinction in France for his general contribution to society: the Légion d'Honneur.

A visionary, tireless and meticulous scientist, relentlessly cataloguing the progress of the successive demonstrations of his hypotheses over 50 years, unwavering in his refusal to be influenced by the contrary opinions of his contemporaries or the economic interests of industrial lobbies, he was a genuine researcher, always young, always ready to question scientific prejudices, always open to the most audacious hypothesis, with an open mind and heart.

\section{References}

1. Selyé H, Renaud S. Humoral conditioning for production of acute massive myocardial necroses by neuromuscular exertion. P Soc Exp Biol Med 1957;96:512-4.

2. Lagarde M, Lanzmann-Petithory D. Obituary-Serge C. Renaud. Prostag Leukotr Ess 2013;88:147-8.

3. Renaud S, de Lorgeril M, Delaye J, et al. Cretan Mediterranean diet for prevention of coronary heart disease. Am J Clin Nutr
1995;61:1360-7.

4. CBS. 60 Minutes program. Available from: http://www.renaudsociety.org/

5. Renaud S, deLorgeril M. Wine, alcohol, platelets, and the French paradox for coronary heart disease. Lancet 1992;339:15236.

6. Ruf JC, Berger JL, Renaud SC. Platelet rebound effect of alcohol withdrawal and wine drinking in rats. Relation to tannins and lipid peroxidation. Arterioscl Throm Vas 1995;15:140-4.

7. Renaud SC, Beswick AD, Fehily AM, et al. Alcohol and platelet aggregation: the caerphilly prospective heart disease study. Am J Clin Nutr 1992;55:1012-7.

8. Renaud S, Lanzmann-Petithory D, Guegen R, Conard P. Alcohol and mortality from all causes. Biol Res 2004;37:183-7.

9. Klatsky A, Udaltsova N. Alcohol drinking and total mortality risk. Ann Epidemiol 2007;17:63-7.

10. Lanzmann-Petithory D. Commentary on Kerr et al. (2013): the French Paradox versus binge drinking. Addiction 2013;108: 1049-50.

11. Ruidavets JB, Ducimetière $P$, Evans A, et al. Patterns of alcohol consumption and ischaemic heart disease in culturally divergent countries: the prospective epidemiological study of myocardial infarction (PRIME). Brit Med J 2010;341:6077.

12. Mukamal KJ, Maclure M, Muller JE, Mittleman MA. Binge drinking and mortality after acute myocardial infarction. Circulation 2005;112:3839-45.

13. Arif AA, Rohrer JE. Patterns of alcohol drinking and its association with obesity: data from the Third National Health and Nutrition Examination Survey, 1988-1994. BMC Public Health 2005;5:126.

14. World Health Organization. Global health observatory data repository, 2008. Available from: http://apps.who.int/ gho/data/node.main

15. Thierry Mathe T, Francou A, Colin J, Hebel P. Comparaison des modèles alimentaires français et états-uniens. French eating habits compared to Americans. CREDOC, Research Center for the study and observation of living conditions, 2012. Available from: http://www.credoc.fr/pdf/4p/255.pdf

16. Renaud S, Guéguen R, Siest G, Salamon R. Wine, beer and mortality in middle-aged men from Eastern France. Arch Intern Med 1999;159:1865-70.

17. Renaud S, Guegen R, Conard P, et al. Wine reduces hypertension related mortality: a prospective cohort study in French men. Am J Clin Nutr 2004;80:621-5.

18. Simini B. Serge Renaud: from French paradox to Cretan miracle. Lancet 2000;355:48. 